\title{
A study of eating habits among female nursing students in the university of Babylon/Iraq
}

\author{
Salma KJ, ${ }^{a}$ Wafaa AA, ${ }^{b}$ Zainab $A^{c}$
}

aDepartment of Community Health Nursing, College of Nursing, University of Babylon, Iraq.

${ }^{b}$ Department of Maternal and Child Health Nursing, College of Nursing, University of Babylon, Iraq.

'Graduate Nurse, College of Nursing, University of Babylon, Iraq.

Correspondence to Salma KJ (email: salmakadhhum972@gmail.com).

(Submitted: 6 September 2016 - Revised version received: 20 September 2016 - Accepted: 3 October 2016 - Published online: 26 December 2016)

\begin{abstract}
Objectives To assess socio demographic characteristics, the responses of eating habits among female nursing students and to determine the relationship between the socio demographic characteristics and the responses of eating habits.

Methods A descriptive analytic design was conducted on a purposive sample of 100 female nursing students in the University of Babylon. A questionnaire has been used as a tool of data collection and consisting of socio demographic, the general responses, the responses related to dietary activity, behavioral responses of eating habits, data collected from the period of March 1 to June 20, 2016.

Results The results of the study revealed that $64.0 \%$ of women aged between 22 and 24 years with Mean \pm SD $(52.46 \pm 11.70), 61.0 \%$ of sample were found at grade 3 of study, $81.0 \%$ were single, $96.0 \%$ were home resident, $77.0 \%$ their original address in urban area, $86.0 \%$ study sample were not working. $56.0 \%$ were economic status satisfied to some extent. $67.0 \%$ were normal weight. $72.0 \%$ were non-dieting regimen. There is a significant relationship found between the demographical characteristics and responses related to dietary activity factors in like original address, marital status, and also between general responses and demographical characteristics, such as age groups, present BMI, and significant relationship between behavioral responses and demographical characteristics variables with occupation at $P \leq 0.05$.

Conclusion The study recommends that family can encourage their daughters to choose the healthiest food collections and schools, universities will assist in minimizing the consumption of fast foods and others.

Keywords eating habits, female, nursing students
\end{abstract}

\section{Introduction}

People who wish to be fit should adapt to the ideal habits and behave differently. Gain knowledge of adopt and apply the habits, is the right way to achieve the success. ${ }^{1}$

Residing in the university and college is potentially an important intention for the promotion of healthy lifestyles of the adult population. Though information about the body mass index (BMI) distribution and nutritional and healthrelated behaviors are still few, the majority of students having a desire to be thinner. ${ }^{2}$

Students', who join the university, dining plans are dealing daily with the food setting characterized by foods high in energy, fats, and added sugars, and low in nutrient density. This will put them in challenges what decide to eat beside having their food currently in an environment where no nutrition labeling is needed.

Dietary patterns developed during adolescence may contribute to obesity and eating disorders and may increase the risk for several important chronic diseases later in life. ${ }^{4}$

Throughout a person's life, certain events will occur which is of particular importance and is considered as a turning point in their lives. Breakfast as an example is the most important meal in the dietary plan of an adolescent.

Adequate intake of animal and plant sources of protein is vital for adolescence. Vitamins and minerals such as calcium, iron, and iodine must be included in the adolescents' diet. Best sources of vitamins are fruits and vegetables while milk and dairy products are the best sources of calcium. ${ }^{6}$

Today, the foods of Iraq reflect this rich inheritance as well as strong influences from the culinary traditions of Turkey and Iran and the Greater Syria area. Because of all these traditions and complex influences, Iraqi cuisine is enormously rich and varied. ${ }^{7}$

Most Asian countries have been shifting towards a diet higher in fat and meat, and lower in carbohydrates and fiber. Additionally, decreased levels of physical activity and leisure are linked to increases in the prevalence of an overweight condition, obesity and diet-related non-communicable diseases, although the prevalence of students who were overweight was very low in this study sample. ${ }^{8}$ Being tense and having fear of gaining weight or becoming fat even if at normal weight or underweight is another pattern of eating habits as one of the girls deal as well as unsuitable balance behavior to prevent weight gain such as self-induced vomiting; misuse of laxatives, diuretics, enemas or other medications; fasting; or excessive exercise. ${ }^{9}$

\section{Methodology \\ Design of the Study}

A descriptive analytic study.

\section{Sample of the Study}

The probability (purposive sampling) was selected by a randomized system which consists of (100) female nursing students.

\section{Setting of the study}

The data were collected from the period between March 1 and June 20, 2016 at the College of Nursing, University of Babylon. 


\section{Instruments}

The questionnaire was constructed for the purpose of the study. The instruments consisted four parts as below:

Part 1: Demographic Date Sheet: This part concerned with personal information include, the students age, grade, marital status, occupation, economic status, place of residence recently, original address, present body mass index, and dieting state at present.

Part 2: Responses, 13 items as general responses.

Part 3: Responses related to dietary activities, 12 items.

Part 4: Behavioral responses, 6 items.

These items are rated according to three level Likert scale (Always, Sometimes, and Never) and scored 3, 2, 1, respectively. The data were analyzed using the Statistical Package for Social Sciences (SPSS) version 19. Through the application of descriptive statistical data analysis include (Frequencies, Percentages, and Cumulative Percent) and arithmetic mean with standard deviation, Mean of score (M.S.) with their Standard Deviation (SD), Cutoff point $=3+2+1 / 3=2$ and inferential statistics, and Relative Sufficiency (R.S.\%), and their assessment by cutoff point $(66.67 \%)$ due to scores $(1,2,3)$ which are reported Pass and Failure (Under / Upper), as well as reassessment scoring by (Bad, Moderate, and Good) through the intervals ("33.3355.54”, “55.55-77.76”, and “77.77-100”), respectively.

\section{Results}

Table 1 shows the highest percentage of the sample reported at age ranged between 22 and 24 years, and they are accounted $64 \%$, with mean age and standard deviation $22.01 \pm 1.360$. The greater number of them in third grade, and they are accounted $61 \%$. The highest percentage of the sample place of residence recently was at home, and they are accounted (96\%) while sample represents Urban residency at $77 \%$. The majority of participants are not working. They constitute (86\%). The study revealed that $56 \%$ of their economic status was satisfied to some extent, the greater number of them with normal BMI, they are accounted $67 \% .72 \%$ of the sample was not on dieting regimen.

Table 2 shows the highest percentage representing $40.0 \%$ of study samples answer sometimes "I am terrified about being overweight". $47.0 \%$ of study samples were sometimes "avoid eating when hungry", $41.1 \%$ of them were "always avoid soft drinks", $47.0 \%$ of study participants were "sometimes cut food into small pieces", $39.0 \%$ of study samples were "sometimes aware of the calorie content of food", (36.0\%) of study samples were "always avoid food with a high carbohydrate content" i.e. (bread, rice, potatoes, etc.), (77.0\%) of students answer they "never vomit after eating", (46.0\%) of study subjects were "never guilty after eating", ( $52.0 \%$ ) of study samples were "sometimes think about burning up calories when exercising", (48.0\%) of population sample said "sometimes I take longer than others to eat my meals", (45.0\%) of study sample were "never eat diet foods", (40.0\%) of study samples were "sometimes feel that food controls their life", (50.0\%) of study samples were "sometimes 1 display self-control around food", (41.0\%) of study sample answer they "never feel that others pressure them to eat". Table 3 shows the highest percentage representing $40.0 \%$ of study sample answer sometimes I give too much time and thought to food, $47.0 \%$ of them were sometimes feel uncomfortable after eating sweets and

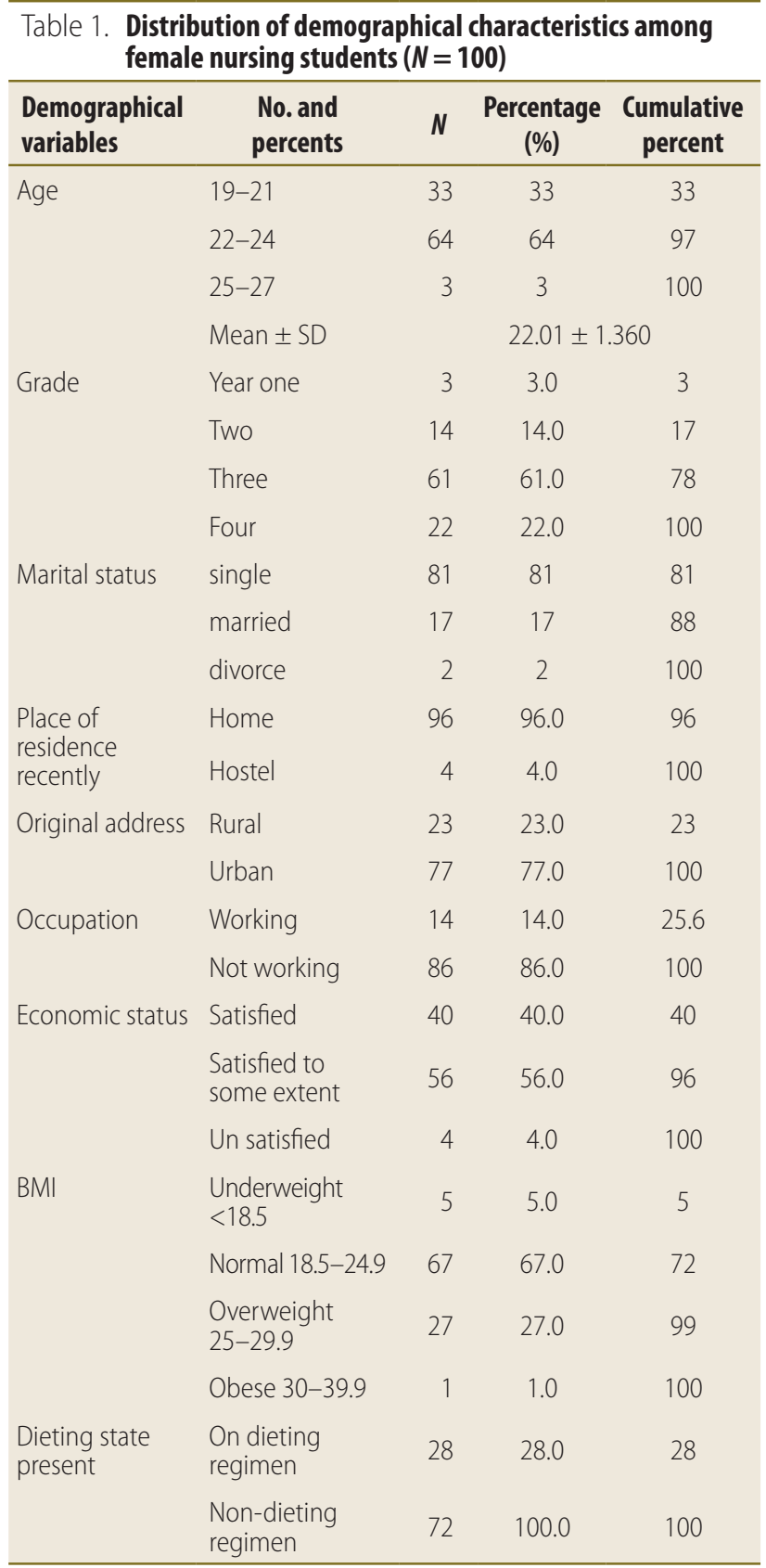

sugar, $43.0 \%$ of study sample was never engage in dieting behavior, and never like stomach to be empty, $48.0 \%$ of study samples were sometimes enjoy trying new rich foods, $41.0 \%$ of study samples were sometimes skipped breakfast, majority of participants representing 53.0\% were sometimes skipped lunch, $51.0 \%$ of study samples were sometimes consumed at least $1 \leq$ serving daily of dairies, while more than half of them, $58.0 \%$ were sometimes consume one serving of meat and eggs daily, $49.0 \%$ of study sample sometimes consume at least one serving $1 \leq$ serving of fruits and vegetables daily, same time $48.0 \%$ of girls were sometimes taking meals regularly, and $39.0 \%$ of study sample were sometimes taking snacking. Table 4 deals with the behavioral responses, the results show that highest percentage represented $52.0 \%$ of study sample were never gone on eating binges where feeling that unable to stop, while majority of participants accounted $66.0 \%$ of study sample were never (behaving as sick vomited to control or shape, majority of girls represented $71.0 \%$ never (use laxatives, diet pills or diuretics to control their weight 


\begin{tabular}{|c|c|c|c|c|c|c|c|c|}
\hline Response of the sample & Scoring levels & No. & $\%$ & $x^{2}$-test & P-value (*) & MS & SD & RS \\
\hline \multirow{3}{*}{$\begin{array}{l}\text { 1. I am terrified about being } \\
\text { overweight }\end{array}$} & Never & 25 & 25 & 1.9 & 0.772 & 1.90 & .772 & 63.3 \\
\hline & Sometimes & 40 & 40 & & & & & \\
\hline & Always & 35 & 35 & & & & & \\
\hline \multirow[t]{3}{*}{ 2. Avoid eating when I am hungry } & Never & 37 & 37 & 2.2 & 0.701 & 2.21 & .701 & 73.6 \\
\hline & Sometimes & 47 & 47 & & & & & \\
\hline & Always & 16 & 16 & & & & & \\
\hline \multirow[t]{3}{*}{ 3. Cut my food into small pieces } & Never & 37 & 37 & 2.1 & 0.780 & 2.09 & .780 & 69.6 \\
\hline & Sometimes & 47 & 47 & & & & & \\
\hline & Always & 16 & 16 & & & & & \\
\hline \multirow{3}{*}{$\begin{array}{l}\text { 4. I aware of the calorie content } \\
\text { of foods that I eat }\end{array}$} & Never & 35 & 35 & 2.1 & 0.814 & 2.06 & .814 & 68.6 \\
\hline & Sometimes & 39 & 39 & & & & & \\
\hline & Always & 26 & 26 & & & & & \\
\hline \multirow{3}{*}{$\begin{array}{l}\text { 5. I particularly avoid food with a high } \\
\text { carbohydrate content (i.e. Bread, rice, } \\
\text { potatoes, etc.) }\end{array}$} & Never & 36 & 36 & 2.3 & 0.809 & 2.25 & .809 & 75.0 \\
\hline & Sometimes & 34 & 34 & & & & & \\
\hline & Always & 30 & 30 & & & & & \\
\hline \multirow[t]{3}{*}{ 6. I vomit after I have eaten } & Never & 77 & 77 & 2.7 & 0.529 & 2.73 & .529 & 91.0 \\
\hline & Sometimes & 19 & 19 & & & & & \\
\hline & Always & 4 & 4 & & & & & \\
\hline \multirow[t]{3}{*}{ 7. I feel extremely guilty after eating } & Never & 46 & 46 & 2.3 & .0709 & 2.32 & .709 & 77.3 \\
\hline & Sometimes & 40 & 40 & & & & & \\
\hline & Always & 14 & 14 & & & & & \\
\hline \multirow{3}{*}{$\begin{array}{l}\text { 8. I think about burning up calories } \\
\text { when I exercise }\end{array}$} & Never & 21 & 21 & 1.9 & 0.694 & 1.94 & .694 & 64.6 \\
\hline & Sometimes & 52 & 52 & & & & & \\
\hline & Always & 27 & 27 & & & & & \\
\hline \multirow{3}{*}{$\begin{array}{l}\text { 9. I take longer than others to eat } \\
\text { my meals }\end{array}$} & Never & 29 & 29 & 2.1 & 0.722 & 2.06 & .722 & 68.6 \\
\hline & Sometimes & 48 & 48 & & & & & \\
\hline & Always & 23 & 23 & & & & & \\
\hline \multirow[t]{3}{*}{ 10. I eat diet foods } & Never & 45 & 45 & 2.3 & 0.770 & 2.25 & .770 & 75.0 \\
\hline & Sometimes & 35 & 35 & & & & & \\
\hline & Always & 20 & 20 & & & & & \\
\hline \multirow[t]{3}{*}{ 11. I feel that food controls my life } & Never & 39 & 39 & 2.2 & 0.757 & 2.18 & .757 & 72.6 \\
\hline & Sometimes & 40 & 40 & & & & & \\
\hline & Always & 21 & 21 & & & & & \\
\hline \multirow[t]{3}{*}{ 12. I display self-control around food } & Never & 18 & 18 & 1.9 & 0.697 & 1.86 & .697 & 62.0 \\
\hline & Sometimes & 50 & 50 & & & & & \\
\hline & Always & 32 & 32 & & & & & \\
\hline \multirow[t]{3}{*}{ 13. I feel that others pressure me to eat } & Never & 41 & 41 & 2.2 & 0.792 & 2.17 & .792 & 72.3 \\
\hline & Sometimes & 35 & 35 & & & & & \\
\hline & Always & 24 & 24 & & & & & \\
\hline
\end{tabular}

$\left.{ }^{*}\right)$ HS: Highly Sig. at $P<0.01$; S: Sig. at $P<0.05 ;$ N S: Not Sig. at $P>0.05$. The statistics based on the Chi Square test. $X^{2}$ : Chi Square, $P$ : Probability, MS: Mean of Score SD: Standard deviation, RS: Relative sufficiency.

or shape), $64.0 \%$ of study sample were never exercised more than 60 minutes a day to lose or to control weight, $66.0 \%$ of them never lost 20 pounds or more in the past 6 months, $76.0 \%$ of study participants were never been treated for an eating disorder. Table 5 summarizes of the subjects overall responses shows good assessment in regard to behavioral responses. Regarding
"Responses" part results reported (Table 6) no significant relationship with "Demographical Characteristics" variables except with (age groups and present BMI) significant relationship were obtained at $P<0.05$. Table 7 shows no significant relationship between responses related dietary activity element the with demographical characteristics variables except with (marital 


\begin{tabular}{|c|c|c|c|c|c|c|c|c|}
\hline Response related to dietary activity & Scoring levels & No. & $\%$ & $X^{2}$-test & $P$-value (*) & MS & SD & RS \\
\hline \multirow{3}{*}{$\begin{array}{l}\text { 1. I Give too much time and thought } \\
\text { to food }\end{array}$} & Never & 25 & 25 & 18.620 & 0.000 & 2.14 & 0.682 & 71.3 \\
\hline & Sometimes & 40 & 40 & & & & & \\
\hline & Always & 35 & 35 & & & & & \\
\hline \multirow{3}{*}{$\begin{array}{l}\text { 2. I Feel uncomfortable after eating } \\
\text { sweets and sugar }\end{array}$} & Never & 37 & 37 & 3.620 & 0.154 & 2.04 & 0.764 & 68.0 \\
\hline & Sometimes & 47 & 47 & & & & & \\
\hline & Always & 16 & 16 & & & & & \\
\hline \multirow{3}{*}{ 3. I Engage in dieting behavior } & Never & 43 & 43 & 10.820 & 0.004 & 2.25 & 0.744 & 75.0 \\
\hline & Sometimes & 39 & 39 & & & & & \\
\hline & Always & 18 & 18 & & & & & \\
\hline \multirow{3}{*}{ 4. I Like my stomach to be empty } & Never & 43 & 43 & 5.420 & 0.067 & 2.19 & 0.800 & 97.0 \\
\hline & Sometimes & 33 & 33 & & & & & \\
\hline & Always & 24 & 24 & & & & & \\
\hline \multirow{3}{*}{ 5. I Enjoy trying new rich foods } & Never & 9 & 9 & 27.020 & 0.000 & 1.66 & 0.639 & 55.3 \\
\hline & Sometimes & 48 & 48 & & & & & \\
\hline & Always & 43 & 43 & & & & & \\
\hline \multirow{3}{*}{ 6. Skipped breakfast } & Never & 29 & 29 & 2.660 & 0.264 & 1.99 & 0.722 & 66.6 \\
\hline & Sometimes & 41 & 41 & & & & & \\
\hline & Always & 30 & 30 & & & & & \\
\hline \multirow{3}{*}{ 7. Skipped lunch } & Never & 35 & 35 & 25.340 & 0.000 & 2.23 & 0.649 & 74.3 \\
\hline & Sometimes & 53 & 53 & & & & & \\
\hline & Always & 12 & 12 & & & & & \\
\hline \multirow{3}{*}{$\begin{array}{l}\text { 8. Consumed at least ( } 1 \leq \text { serving) } \\
\text { daily of dairies }\end{array}$} & Never & 31 & 31 & 16.580 & 0.000 & 2.12 & 0.691 & 70.6 \\
\hline & Sometimes & 51 & 51 & & & & & \\
\hline & Always & 18 & 18 & & & & & \\
\hline \multirow{3}{*}{$\begin{array}{l}\text { 9. Consume one serving of meat } \\
\text { and eggs daily }\end{array}$} & Never & 25 & 25 & 4.460 & 0.108 & 2.08 & 0.646 & 69.3 \\
\hline & Sometimes & 58 & 58 & & & & & \\
\hline & Always & 17 & 17 & & & & & \\
\hline \multirow{3}{*}{$\begin{array}{l}\text { 10. Consume at least one serving } \\
(1 \leq \text { serving)of fruits and } \\
\text { vegetables daily }\end{array}$} & Never & 17 & 17 & 28.340 & 0.000 & 1.83 & 0.697 & 61.0 \\
\hline & Sometimes & 49 & 49 & & & & & \\
\hline & Always & 34 & 34 & & & & & \\
\hline \multirow{3}{*}{ 11. Taking meals regularly } & Never & 32 & 32 & 11.840 & 0.003 & 2.12 & 0.715 & 70.6 \\
\hline & Sometimes & 48 & 48 & & & & & \\
\hline & Always & 20 & 20 & & & & & \\
\hline \multirow{3}{*}{ 12. Taking snacking } & Never & 28 & 28 & 1.820 & 0.403 & 1.95 & 0.783 & 65.0 \\
\hline & Sometimes & 39 & 39 & & & & & \\
\hline & Always & 33 & 33 & & & & & \\
\hline
\end{tabular}

$\left(^{*}\right) \mathrm{HS}$ : Highly Sig. at $P<0.01$; S: Sig. at $P<0.05$; NS: Not Sig. at $P>0.05$. The statistics based on the Chi Square test. $X^{2}$ : Chi Square, $P$ : Probability of chance, MS: Mean of Score, SD: Standard deviation, RS: Relative sufficiency.

status and original address) highly significant correlation were obtained at $P<0.01$. Table 8 shows no significant relationship between behavioral part and the sociodemographic characteristics variables except with occupation significant correlation ships was obtained at $P<0.05$.

\section{Discussion}

The present study identified the eating habits among female nursing students. And aimed to study the eating habits in the context of avoid engaging in the negative eating behaviors. The age group revealed that students are in the middle ages, cultural, socio economic and some health attitudes play an important role in the development of eating habits. A study conducted in Sudan by (Elhassan) found that the age of most students was ranging from 19 to 24 years. ${ }^{10}$ The greater number of them in third grade. As the university students may need hostel, the results revealed that the majority are living at their homes, staying with the family may change the habits of students. ${ }^{11}$ This agree with the present study when they reported 


\begin{tabular}{|c|c|c|c|c|c|c|c|c|}
\hline Behavioral responses & Scoring levels & No. & $\%$ & $x^{2}$-test & $P$-value (*) & MS & SD & RS \\
\hline \multirow{3}{*}{$\begin{array}{l}\text { 1. Gone on eating binges where } \\
\text { you feel that you may not be } \\
\text { able to stop }\end{array}$} & Never & 52 & 52 & 20.540 & 0.000 & 2.37 & 0.734 & 79.0 \\
\hline & Sometimes & 33 & 33 & & & & & \\
\hline & Always & 15 & 15 & & & & & \\
\hline \multirow{3}{*}{$\begin{array}{l}\text { 2. Ever made yourself sick } \\
\text { (vomited) to control your } \\
\text { weight or shape }\end{array}$} & Never & 66 & 66 & 51.860 & 0.000 & 2.57 & 0.655 & 85.6 \\
\hline & Sometimes & 25 & 25 & & & & & \\
\hline & Always & 9 & 9 & & & & & \\
\hline \multirow{3}{*}{$\begin{array}{l}\text { 3. Ever used laxatives, diet pills or } \\
\text { diuretics (water pills) to control } \\
\text { your weight or shape }\end{array}$} & Never & 71 & 71 & 68.180 & 0.000 & 2.65 & 0.592 & 88.33 \\
\hline & Sometimes & 23 & 23 & & & & & \\
\hline & Always & 6 & 6 & & & & & \\
\hline \multirow{3}{*}{$\begin{array}{l}\text { 4. Exercised more than } 60 \text { minutes } \\
\text { a day to lose or to control your } \\
\text { weight }\end{array}$} & Never & 64 & 64 & 50.960 & 0.000 & 2.58 & .606 & 86.0 \\
\hline & Sometimes & 30 & 30 & & & & & \\
\hline & Always & 6 & 6 & & & & & \\
\hline \multirow{3}{*}{$\begin{array}{l}\text { 5. Lost } 20 \text { pounds or more in the } \\
\text { past } 6 \text { months }\end{array}$} & Never & 66 & 66 & 49.520 & 0.000 & 2.54 & 0.702 & 83.3 \\
\hline & Sometimes & 22 & 22 & & & & & \\
\hline & Always & 12 & 12 & & & & & \\
\hline \multirow{3}{*}{$\begin{array}{l}\text { 6. Have you ever been treated for } \\
\text { an eating disorder }\end{array}$} & Never & 76 & 76 & 84.061 & 0.000 & 2.66 & 0.673 & 88.6 \\
\hline & Sometimes & 13 & 13 & & & & & \\
\hline & Always & 11 & 11 & & & & & \\
\hline
\end{tabular}

${ }^{\left({ }^{7} H S\right.}$ : Highly Sig. at $P<0.01$; S: Sig. at $P<0.05$; NS: Not Sig. at $P>0.05$. The statistics based on the Chi Square test. $X^{2}$ : Chi Square, $P$ : Probability of chance, MS: Mean of Score, SD: Standard deviation, RS: Relative sufficiency.

\begin{tabular}{|c|c|c|c|c|c|c|}
\hline Dietary habits & No. & Min. & Max. & GMS. & RS. & Ass. \\
\hline General responses & 100 & 1.8 & 2.7 & 2.25 & 71.81 & Mod. \\
\hline $\begin{array}{l}\text { Response related to } \\
\text { dietary activity }\end{array}$ & 100 & 1.66 & 2.25 & 1.95 & 70.3 & Mod. \\
\hline Behavioral responses & 100 & 2.37 & 2.66 & 2.515 & 85.1 & Good \\
\hline
\end{tabular}

\begin{tabular}{|c|c|c|c|}
\hline KE & & eral tesp & \\
\hline demographical characteristics & C.C. & Sig. & C.S. \\
\hline Age groups & 0.780 & 0.013 & $S$ \\
\hline Grade & 0.534 & 0.869 & NS \\
\hline Marital status & 0.518 & 0.346 & NS \\
\hline Occupation & 0.392 & 0.381 & NS \\
\hline Socio-economic status & 0.518 & 0.346 & NS \\
\hline Place of residence recently & 0.480 & 0.665 & NS \\
\hline Original address & 0.445 & 0.102 & NS \\
\hline Present BMI & 0.951 & 0.041 & S \\
\hline Dieting state now & 0.400 & 0.324 & SN \\
\hline
\end{tabular}

${ }^{*}$ S: Sig $P<0.05$; NS: Non Sig. at $P>0.05 ;$ C.C.: Contingency coefficients; C.S: Comparison significant.

that a mean study career of $3.0 \pm 1.0$ years and mentioned that more than half of the participants living at parental home and consumed more fruit and vegetables than those who resided outside of their family home. Our results further indicate that

\begin{tabular}{|c|c|c|c|}
\hline \multirow{2}{*}{$\begin{array}{l}\text { Relationship between } \\
\text { responses related to dietary } \\
\text { activity factors and demographical } \\
\text { characteristics variables }\end{array}$} & \multicolumn{3}{|c|}{$\begin{array}{l}\text { Responses related to dietary } \\
\text { activity }\end{array}$} \\
\hline & C.C. & Sig. & C.S. \\
\hline Age groups & 0.635 & 0.969 & NS \\
\hline Grade & 0.492 & 0.784 & NS \\
\hline Marital status & 0.628 & 0.000 & HS \\
\hline Occupation & 0.37 & 0.246 & SN \\
\hline Socio-economic status & 0.381 & 0.911 & NS \\
\hline Place of residence recently & 0.282 & 0.999 & NS \\
\hline Original address & 0.473 & 0.007 & $\mathrm{HS}$ \\
\hline Present BMI & 0.983 & 0.032 & NS \\
\hline Dieting state now & 0.341 & 0.436 & SN \\
\hline
\end{tabular}

the subjects who are working while they study are only some, having a budget may help students improve their eating selections, at the same time, the study revealed that part of our elements are moderately satisfied economically, These findings were consistent with (Reyes) who indicated that money becomes the overwhelming factor (with 49.1\%) of the sample when looking at working and lower-middle class students. ${ }^{12}$ The data showed that a majority of students would eat healthier if money was not a factor in deciding what to eat. With regard to BMI, greater number of them with the normal level, and not on dieting regimen at present time. A finding that is consistent with a study of (Majors). The results show that on average nutrition and non-nutrition students where within a normal BMI. 
Table 8. Relationship between behavioral responses factors and demographical characteristics variables among 100 students

\begin{tabular}{lccc}
\hline $\begin{array}{l}\text { Relationship between } \\
\text { behavioral responses } \\
\text { factors and demographical } \\
\text { characteristics variables }\end{array}$ & \multicolumn{3}{c}{ Behavioral Responses } \\
\cline { 2 - 4 } Age groups & C.C. & Sig. & C.S. \\
Grade & 0.650 & 0.177 & NS \\
Marital status & 0.399 & 0.873 & NS \\
Occupation & 0.320 & 0.875 & NS \\
Socio-economic status & 0.415 & 0.014 & S \\
Place of residence recently & 0.380 & 0.533 & NS \\
original address & 0.220 & 0.825 & NS \\
present BMl & 0.909 & 0.318 & NS \\
Dieting state now & 0.288 & 0.434 & SN \\
\hline
\end{tabular}

\section{General Responses}

This portion deals with eating responses in general, it is amazing to know that most of the items are considered as eating attitude and lifestyle practices and some can be as self-report to determine whether there is any eating disorder that needs professional attention. The current data show that girls demonstrated moderate to good reaction toward the eating attitudes, except with some of items that their answers show some fear from being overweight, think about burning up calories when exercise, show self-control around food and the effect of others on pattern of eating. These findings were consistent with (Alavi) who found that dietary behaviors of the majority of participants per evaluation were on the medium level (41 percent) with the participants' attitude in most cases was very positive. ${ }^{14}$

And agree with so many studies as (Yahia) who illustrated that the university girls see the shape and weight of fashion models as the ideal body shape and figure to attain. Girls with such strong body weight perception can be at risk of developing eating disorders. ${ }^{15}$ Other portions like this study revealed what (Musaiger) pointed out it is important to limit carbohydrate consumption, it is important to limit the amount of fat, About $42 \%$ and $81 \%$ of physicians and medical students, respectively, did not know the correct percentage of energy needed from fat, carbohydrates, and protein in a healthy diet. ${ }^{16}$ Also consistent with (Alakaam) Marywood University (USA) who found that, most of the students (80\%) said that meals are home cooked, occur mostly at homes on a daily basis, are varied, filling, and small in portion size, and take place at a specific time during the day. While disagreeing with the fact of guilt feeling when pointed-out that several participants reported feelings of guilt in the US due to eating more meals and consuming unhealthy food.

\section{Responses Related to Dietary Activity}

The results of this table demonstrated that the sample activities mainly of acceptable level, only with regard to trying new rich foods and eating less than required fruits and vegetables daily ${ }^{18}$ agree with the current study girls less frequently consumed breakfast, fruits, milk, sugar-sweetened drinks, and energy drinks, but significantly more frequently consumed French fries/potato chips, cakes/donuts, and sweets/chocolates. While the study came with that some healthy dietary activities like students are not Skipped breakfast or Skipped lunch. (Alavi) found that the $48.4 \%$ of the participants are not eating breakfast, $62.7 \%$ dairy products, and $27.7 \%$ meat and eggs. ${ }^{14}$

\section{Behavioral Responses}

Results further indicate that these latter determinants become more vital when the population sample demonstrated that all their eating behavior come pass and away from having an eating disorder, their assessment indicated that for example do not try to vomit after eating or using laxatives, diet pills or diuretics to control weight or shape and so on. The results are consistent with (Payne) indicated that $20 \%$ of the study sample participated in binge eating, $21 \%$ fasted, $3 \%$ vomited and $2 \%$ admitted to laxative misuse, resulting in an overall eating disorder. ${ }^{19}$ With regard to physical activities, the sample show that sample less exercised more than $60 \mathrm{~min}$ a day to lose or to control their weight (Musaiger) showed that the mean number of minutes performing physical activity per week was significantly higher among boys than girls. ${ }^{20}$

\section{Conclusion}

Based on the findings of this study, it can be concluded that the overall responses of nursing students is Moderate in General, and related to dietary activity it came good in behavioral assessment. However, it is found that there is a significant relationship between general responses. Factors and demographical characteristics (Age groups and present BMI) also have a high significant relationship between responses related to dietary activity. Factors and marital status as well as original address, finally a significant relationship between behavioral responses and sample occupation was found.

\section{Recommendations}

Family can help grills in adopting healthy habits when selecting food collections, activating the educational programs as early as in adolescence about the importance of body image for females through giving health information to maintain healthy body. Schools and universities have a good role in encouraging the students to make their meals as fresh as possible and minimizing the fast foods and others. Motivate the population to stop imitating the others in unhealthy nutritional practices.

\section{Conflict of interest}

None.

\section{References}

1. Johnson C. 10 eating habits of the highly successful and fit: Women's Health (2012)

2. Sakamaki R, Amamoto R, Mochida Y, Shinfuku N, Toyama K. A comparative study of food habits and body shape perception of university students in Japan and Korea. Nutr J. 2005:4:31

3. Kolodinsky J, Harvey-Berino JR, Berlin L, Johnson RK, Reynolds TW. Knowledge of current dietary guidelines and food choice by college

students: better eaters have higher knowledge of dietary guidance. J AM Diet Assoc. 2007;107:1409-1413.

4. Neumark-Sztainer D, Story M, Hannan PJ, Croll J. Overweight status and eating patterns among adolescents: where do youths stand in comparison with the healthy people 2010 objectives. Am J Pub Health. 2002;92:844-851.

5. Afaghi A, Mohamadi HA, Ziaee AA, Sarchami R. Effect of an integrated case-based nutrition curriculum on medical education at Qazvin 
University of Medical Sciences, Iran. Glob J Health Sci. 2012 4:112-117.

6. Hallström L, Vereecken CA, Labayen I, Ruiz JR, Le Donne C, García MC, et al. Breakfast habits among European adolescents and their association with sociodemographic factors: the HELENA (Healthy Lifestyle in Europe by Nutrition in Adolescence) study. Public Health Nutr. 2012;15:1879-1889.

7. Salloum H. Foods of Iraq: enshrined with a long history. Things Asian. 2006;1.

8. Sakamaki R, Toyama K, Amamoto R, Liu C, Shinfuku N. Nutritional knowledge, food habits and health attitude of Chinese university students - a cross sectional study. Nutrition J. 2005;4:4

9. American Psychiatric Association. Diagnostic and statistical manual of mental disorders, Fourth edition, Arlington. American Psychiatric Publishing, Inc. 2000

10. Elhassan MR, Gamal HE, Mohammed GS. Nutrition knowledge attitude and practices among students of Ahfad University for Women. Indian J Sci Res. 2013:4:25-34.

11. Deliens T, Clarys P, Bourdeaudhuij ID, Deforche B. Determinants of eating behaviour in university students: a qualitative study using focus group discussions. BMC Public Health. 2014;14:53.

12. Reyes AM. Influences on College Students'Eating Habits University Libraries. University of Arizona. Thesis. 2016;1-11.

13. Majors MR. Dietary habits and knowledge of college students. Theses and Dissertations —-Dietetics and Human Nutrition. 2015;3-33.
14. Alavi M, Eftekhari MB, Noot R, Rafinejad J, Chinekesh A. Dietary habits among adolescent girls and their association with parental educational levels. Global J Health Sci. 2013;5:202-206.

15. Yahia N, AchkarA, Abdallah A, Rizk S. Eating habits and obesity among Lebanese university students. Nutr J. 2008;7:32.

16. Musaiger A, Al-Hazzaa HM. Eating habits, inactivity, and sedentary behavior among adolescents in Iraq: Sex differences in the hidden risks of noncommunicable diseases. Food and Nutrition Bulletin. 2014:35(1):12-18.

17. Alakaam AA, Castellanos DC, Bodzio J, Harrison L. The factors that influence dietary habits among international students in the united states. Journal of International Students. 2015;5(2):104-120.

18. Al-Hazzaa HM, Abahussain NA, Al-Sobayel HI, Qahwaji DM, Musaiger AO. Lifestyle factors associated with overweight and obesity among Saudi adolescents. BMC Public Health. 2012;12:354.

19. Payne KF. A comparative study of dietary habits among college students at-risk and not-at-risk for eating disorders and how such habits compare to the Dietary Guidelines, Thesis. 2008:1-115.

20. Musaiger AO, Al-Mufty BA, Al-Hazzaa HM. Eating habits, inactivity, and sedentary behavior among adolescents in iraq: sex differences in the hidden risks of non communicable diseases. Food Nutr Bull. 2014;35:12-18. 